\section{Effects of Coffee Intake and Intraperitoneal Caffeine on Bone Repair Process - A Histologic and Histometric Study}

\author{
Rander Moreira Macedo, Luiz Guilherme Brentegani, Suzie Aparecida de Lacerda
}

Department of Stomatology, Public Health and Forensic Dentistry, School of Dentistry of Ribeirão Preto, USP - University of São Paulo, Ribeirão Preto, SP, Brazil

Correspondence: Profa. Dra. Suzie Aparecida de Lacerda, Avenida do Café, S/N, 14040-904 Ribeirão Preto, SP, Brasil. Tel: +55-16-33154041. e-mail suzie@forp.usp.br

\begin{abstract}
Studies have suggested that caffeine acts on bone promoting an increase of calcium excretion, inhibition of osteoblast proliferation and delay in tissue repair process, raising the risk of fractures, osteoporosis, periodontal disease and affecting the success of bone reconstructive procedures. The aim of this study was to analyze histomorphometrically the process of alveolar bone healing after tooth extraction in rats subjected to daily intake of boiled coffee or intraperitoneal administration of caffeine. Forty-five male rats were divided according to the treatment in Control group (C); Coffee group (CO) - treated with coffee since birth; and Caffeine (CAF) - intraperitoneal injection of aqueous solution of caffeine $1.5 \%(0.2 \mathrm{~mL} / 100 \mathrm{~g}$ body weight) for 30 days. When weighing between $250-300 \mathrm{~g}$ they were anesthetized, subjected to extraction of the maxillary right incisor, and euthanized 7, 21 and 42 days after surgery for histological assessments of bone volume and the quality of formed bone in the dental socket. The qualitative results demonstrated larger amounts of blood clot and immature bone in animals under treatment of pure caffeine compared to coffee and control. Histometric analysis revealed that coffee treatment led to a $40 \%$ drop in bone formation, and caffeine a 60\% drop in comparison to control animals (ANOVA $p \leq 0.01$ ). It was concluded that both the daily ingestion of coffee and the intraperitoneal administration of caffeine in rats delayed the alveolar bone reparative process after tooth extraction, and this effect was more aggressive when pure caffeine was used.
\end{abstract}

Key Words: coffee, caffeine, bone repair, dental socket, histomorphometry.

\section{Introduction}

The healing process after a dental extraction implies a series of cellular and tissue-related events with the final objective of restoring homeostasis of the area (1). This phenomenon is extremely coordinated and the inflammatory reaction is closely intertwined with the repair (2). These processes may be modified by various known and unknown influences, frequently preventing the quality of both inflammatory response and repair. After tooth extraction, the body fills the space left in the socket with bone, so that the repair is completed when the alveolar bone trabeculae are thick, the marrow spaces tiny and alveolar crest is completely remodeled (3).

Several endogenous and exogenous factors control the formation, resorption and remodeling of bone tissue (2), like consumption of coffee/caffeine. Caffeine is a methyl xanthine naturally found in many drinks, food, medications and dietary supplements, and it is consumed by the great majority of the world population (4). Caffeine has a variety of cellular and pharmacological responses, producing biological effects such as anti-oxidation, anti-mutation, angiogenic, antibiotic action, anti-hypercholesterolemia, anti-hypertension and anti-inflammatory (5).

While some studies have suggested that the effects of coffee/caffeine on bone metabolism are still controversial
(6), others have reported that caffeine, a major constituent of coffee, is associated with a significant increase of periodontal diseases (7), fracture of osteoporotic bones (8), increase in urinary calcium and decrease of bone mineral density (6), as well as delay in bone repair process (9). Also, caffeine has an additional deleterious effect when administrated to animals with osteoporotic bones (10).

The number of patients who need surgical procedures involving bone tissue, such as dental extraction, bone with grafts, bone fractures union and placement of osseointegrated dental implants are on the rise, and consumption of coffee and products containing caffeine is high in modern society. It is therefore important to evaluate the degree of bone alterations during the repair process concomitant to their use.

The aim of this study was to assess histomorphometrically the effects of daily intake of coffee or daily intraperitoneal administration of aqueous solution of caffeine on the alveolar bone repair process after tooth extraction in rats.

\section{Material and Methods}

All the procedures were conducted in accordance with ethical principles for animal research, as approved by the Ethics Committee for use of Animals of Campus of Ribeirão Preto, University of São Paulo, Brazil, and received 
an anthelminthic for animal use (Systamex; Schering of Brazil, São Paulo, SP, Brazil) for 3 days.

\section{Treatment of Animals}

Forty five Wistar rats (Rattus norvegicus) weighing 250-300 $\mathrm{g}$ were used. The animals were fed a balanced diet (6003 Nuvilab VC-1; Nuvital, Colombo, PR, Brazil) and water. They were housed in plastic boxes $(40 \times 32 \times 17 \mathrm{~cm})$ under controlled lighting ( $12 \mathrm{~h}$ light/12 $\mathrm{h}$ darkness) and temperature $\left(21-25^{\circ} \mathrm{C}\right)$, and were allocated to a treatment group with coffee, caffeine or control.

\section{Adaptation Model to the Intake of Coffee}

Seven female rats were adapted to the ingestion of 50 $\mathrm{mg} / \mathrm{mL}$ (1.2 $\mathrm{mL}$ of infusion coffee/day) of boiled roasted and ground coffee (Utam SA, Ribeirão Preto, SP, Brazil) for 30 days, by reducing the offer of water, as follows: $1^{\text {st }}$ week: $50 \mathrm{~mL}$ water/rat and infusion coffee ad libitum, in separate bottles; 2nd week: $35 \mathrm{~mL}$ water/rat and infusion coffee ad libitum, in separate bottles; 3rd week: $25 \mathrm{~mL}$ water/rat and infusion coffee ad libitum, in separate bottles; 4th week: $10 \mathrm{~mL}$ water/rat and infusion coffee ad libitum, in separate bottles.

The vaginal smear of females was used to determine the mating cycle. The last doses $(10 \mathrm{~mL}$ water and infusion of coffee ad libitum) were maintained during mating and pregnancy. Females that did not get pregnant were removed from the study. Coffee intake was maintained for 15 male pups since birth up to adult age, until weighing between 250-300 g, at which time were operated. The amount of coffee ingested by the animals was estimated based on human daily consumption of 4 cups $(240 \mathrm{~mL})$ per day for a person weighing $60 \mathrm{~kg}$.

\section{Intraperitoneal Administration of Caffeine Solution}

Fifteen animals with the same weight $(250-300 \mathrm{~g})$ received daily intraperitoneal injections of $30 \mathrm{mg} / \mathrm{kg} /$ day of $1.5 \%$ aqueous solution of caffeine (Sigma-Aldrich, St. Louis, MO, USA) for 30 days, when they were ready for operation.

\section{Group Division, Surgical Procedure and Sacrifice}

The animals were divided into 3 groups according to the treatment received: Control (C) with no systemic treatment; Coffee (CO); and Caffeine (CAF). After 60 days of age and coffee intake for group coffee and 30 days of caffeine administration, the animals were anesthetized with an intraperitoneal injection of 2,2,2 tribromoethanol (Tribromoethanol; Sigma-Aldrich, St. Louis, MO, USA); 25 mg per $100 \mathrm{~g}$ body weight. After antisepsis of the area, disconnection of the surrounding gingiva and luxation, the maxillary right incisors were extracted. The soft tissues were sutured with Mononylon 4.0 (Ethicon, São José dos Campos,
$\mathrm{SP}$, Brazil) and the animals received $0.2 \mathrm{~mL}$ of veterinary pentabiotic intramuscularly in a single dose (Wyeth, São Bernardo do Campo, SP, Brazil).

The euthanasia of the animals was done by an overdose of the same anesthetic on the $7^{\text {th }}, 21^{\text {st }}$ and $42^{\text {nd }}$ days after the extraction ( $n=5$ per group). The mandibles were separated from the maxillae, and the right hemi-maxilla was separated from the left one by a sagittal incision along the intermaxillary suture. The maxillary halves were fixed in buffered 10\% formaldehyde solution (pH 7) for $24 \mathrm{~h}$. The specimens were then washed in running water and decalcified with a solution containing $20 \%$ sodium citrate and 30\% formic acid for 6 days. This solution was replaced every 2 days and neutralized with 5\% sodium sulfate. The specimens were then dehydrated by increasing concentration ethanol solution: $70 \%$ overnight, then $80 \%$, $85 \%, 90 \%$, and $95 \%$ for $2 \mathrm{~h}$ each, until 100\%. The specimens were then processed with xylol and embedded in paraffin. Longitudinal semi-serial sections of $5 \mu \mathrm{m}$ thickness were stained with hematoxylin and eosin.

\section{Histologic and Histometric Analyses}

Histological analysis consisted of direct observations of the alveolar area with optical microscope for the presence of inflammatory foreign body reactions, local immune reactions and the quality of the newly formed bone. For histometric analysis, the degree of new bone formation was estimated in the periods of 7,21 , and 42 days after the surgery. A Leica DM LB2 optical microscope (Leica Microsystems Wetzlar GmbH, Wetzlar, Germany) with a Leica DFC 280 digital video camera (Leica Microsystems Imaging AG, Cambridge, England) was used to capture the images that were processed using the Leica Owin program (Leica Imaging Systems Ltd., Cambridge, England). A grid containing 100 equidistant points was superimposed on microscopic image (final magnification 250) of alveolar components. To obtain the bone volume fraction (\%), 5 fields were analyzed in each third of the alveolus (cervical, middle and apical), totalizing 15 fields per alveolus, to estimate the bone percentage volume by a method of differential count of 1500 points per alveolus $(n=5)$.

\section{Statistical Analysis}

Differences between groups were analyzed by parametric ANOVA and Tukey's test ( $p \leq 0.01$ for statistical significance using the GMC statistical software package (available at www.forp.usp.br/restauradora/gmc/gmc.html).

\section{Results}

\section{Histological Analysis}

The qualitative assessment of bone in the dental socket of the animals at 7, 21 and 42 days revealed that in the 
first period, the control group's (C) dental socket was partially filled with delicate and immature bone trabeculae, intermixed in a newly synthesized connective tissue rich in capillaries containing organized masses of blood clot (Fig. 1A). In the group of animals treated with boiled coffee (CO) there were less developed trabeculae and a larger amount of blood clot (Fig. 1B). In animals where caffeine was administered (CAF group), almost all dental sockets also contained blood clots and tiny areas with bone trabeculae in process of new bone formation and calcification (Fig. 1C).

At 21 days, the apical and cervical thirds of control animals (C) were composed of trabecular bone thicker than in the previous period (7 days) (Fig. 1D). In the coffee group (CO) it was observed that trabecular bone was still immature and had a lot of remaining blood clots compared to the control (Fig. 1D). When pure caffeine (CAF) was used, histological analysis showed little newly formed bone and a wide area of blood clot (Fig. 1F).
At 42 days, the control animals showed the dental sockets completely filled by compact trabecular bone, interspersed with a small amount of mature connective tissue (Fig. 1G). In rats that consumed boiled coffee (CO), the bone seemed more mature compared with the 21 days of this group, but less mature than those of the control (Fig. 1H). The intraperitoneal administration of caffeine (CAF) led to trabecular bone with low degree of maturity when compared with animals receiving coffee and controls. It could also be noticed that in some regions of the dental sockets there were blood clots still in the resorption phase (Fig. 11).

\section{Histometric Analysis}

The histometric analysis provided quantitative data showing bone formation along with gradual decrease in the percentage of connective tissue up to 42 days after dental extraction. The control group had the highest percentage
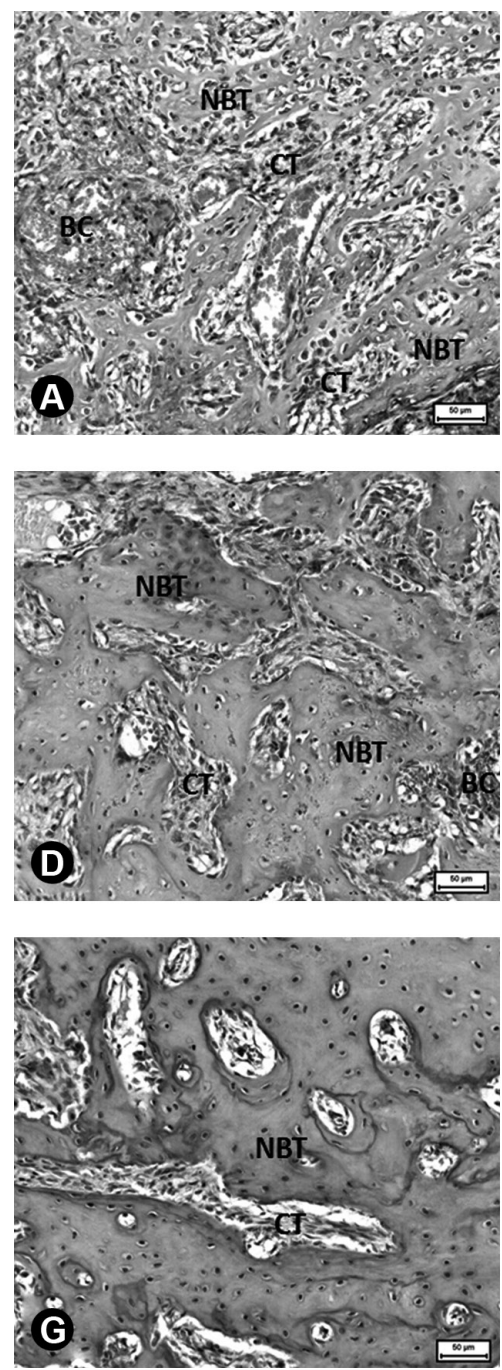
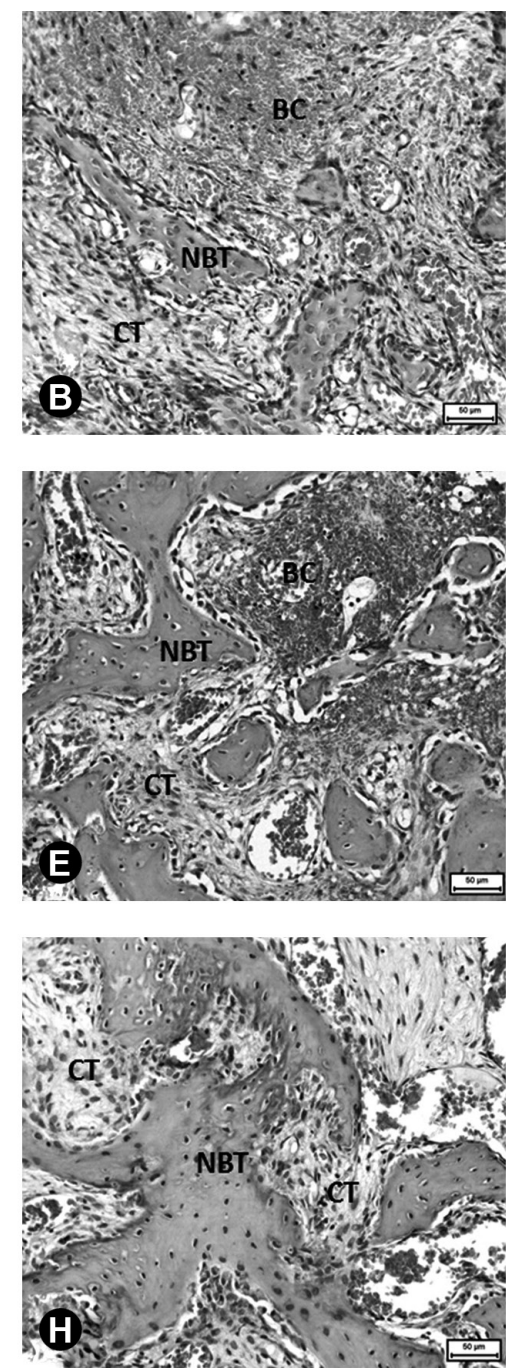
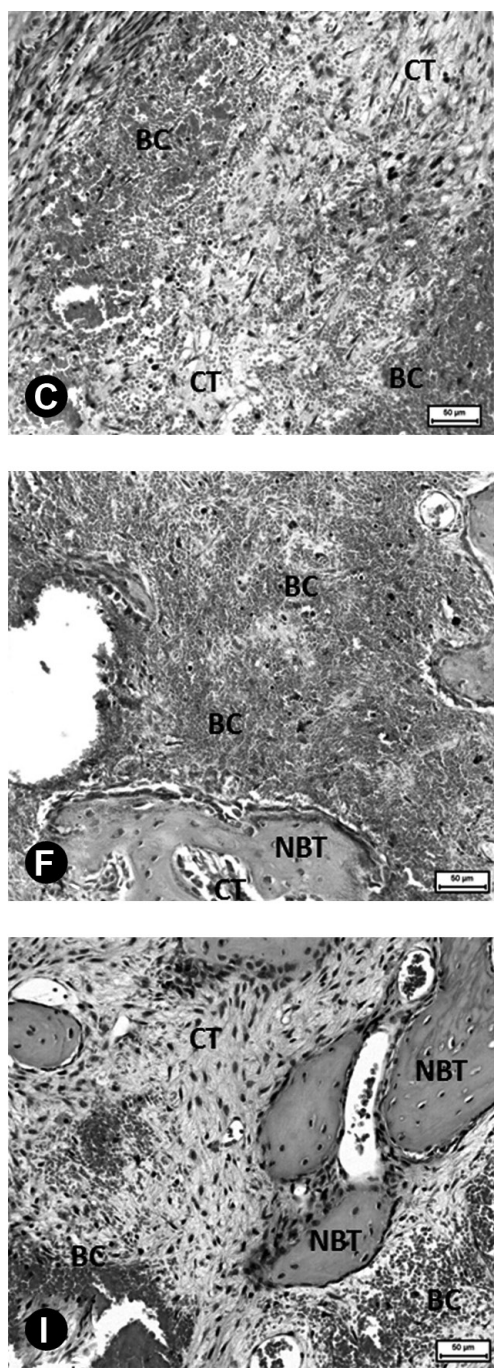

Figure 1. Histological aspects of bone repair after dental extraction in animals of control group (A, D and G); daily coffee intake group (B, E and H) and intraperitoneal caffeine administration group (C, F and 1) on days 7, 21 and 42 after surgical procedures. NBT, newly formed bone tissue; CT, connective tissue, BC, blood clot. Hematoxylin and eosin. 250× magnification. 
of new bone formation for periods of 7, 21 and 42 days when compared with the other groups. In relation to these experimental systemic factors, both the chronic ingestion of boiled coffee and intraperitoneal administration of caffeine promoted a decrease in the percentage of bone deposition inside the dental socket, as confirmed by the statistically significant $(p \leq 0.01)$ low percentages compared with control, in all three periods. The animals that received coffee treatment had a delay in bone formation of $43.71 \%$, $36.15 \%$ and $25.95 \%$ on $7^{\text {th }}, 21^{\text {st }}$ and $42^{\text {nd }}$ day respectively $(p \leq 0.01)$ (Fig. 2). The percentage of newly formed bone in the group that received caffeine during the same periods showed a decrease of $79.60 \%, 50.79 \%$ and $52.28 \%(p \leq 0.01)$ of bone when compared with control (Fig. 2).

\section{Discussion}

The findings of this study reveal that the daily intake of boiled coffee and administration of pure caffeine affected the bone repair process after dental extraction in rats.

The alveolar bone repair offers an appropriate model for the study of bone formation in rats and may be considered a sensitive indicator of bone damage in different experimental conditions $(6,9,10)$. The present methodology used an atraumatic technique that allowed tooth extraction without postoperative complications, to provide a numeric characterization of bone repair process with the interference of systemic factors, analyzed by histological and histometric pattern methods $(6,10)$.

Coffee is one of the most psychoactive beverages consumed around the world, but its effect on bone metabolism is still controversial (11). Studies have suggested that caffeine, a major constituent of coffee, is associated with a significantly increased risk of fractures, osteoporosis, periodontal disease and poor osseointegration of bone grafts $(8,9,12)$.

\section{Newly Formed Bone}

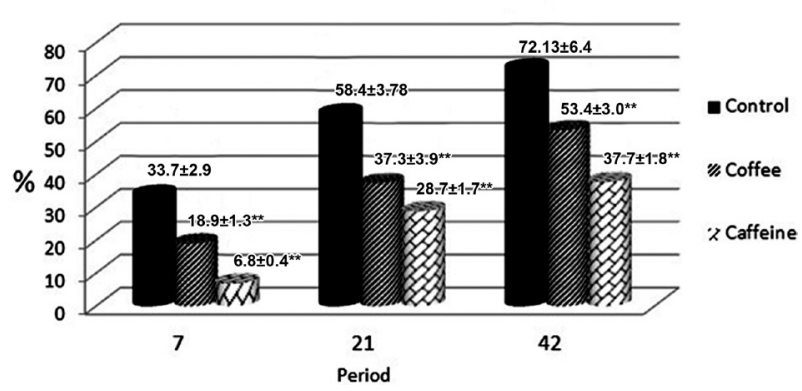

Figure 2. Volume Fraction (\%) of newly formed bone inside the dental socket after dental extraction in animals of control, daily coffee intake and intraperitoneal caffeine administration groups on days 7, 21 and 42 after surgical procedures. Mean \pm standard error of the mean $(n=5)$. **Statistically significant difference comparison with control group (ANOVA, Tukey's test. $\mathrm{p} \leq 0.01$ ).
The adaptation model of coffee intake that was used in this study started from the pregnant female, passing through the early ages of the newborn animals and stabilized in the adult ages, when the rats were ready for surgical procedures, which agrees with the methods described by Lacerda et al. (6). The main intent was a slow adaptation process without causing any metabolic/hydric stress on animals, which could happen if it were tried to change abruptly from water consumption to boiled coffee during the adult age, resulting in an additional negative interference factor in the bone repair process. Furthermore, the objective was to compare coffee intake during the whole life of animals with injected caffeine for a determined period of time, in relation to their intensity to disturb the new bone deposition according to the exposition time.

The histological analysis of the dental sockets of animals that drank coffee and those with caffeine administered intraperitoneally demonstrated large areas containing blood clots, even in late periods ( 21 and 42 days), and delayed the production of granulation tissue compared to control, with greater intensity in animals treated with pure caffeine (Figs. 1C, F and I).

Caffeine acts antagonizing the adenosine receptors $\left(A_{1}\right.$, $A_{2} A_{1} A_{2} B$ and $A_{3}$ ) by changing the function of the enzyme adenil cyclase and activating the kinase $A$ protein (PKA) which increases the intracellular concentrations of cyclic adenosine monophosphate (cAMP) mediator (13), that causes modulation of various aspects of the inflammatory response, and adaptive and innate immune response (14).

Probably both treatments with coffee and pure caffeine could increase the levels of cAMP inside the inflammatory cells in the socket after dental extraction, which resulted in a lower resorptive activity and possibly apoptosis of macrophages, as showed by Jafari and Rabani $(15,16)$, and reduced secretory functions of $\mathrm{T}$ lymphocytes specifically by low production of inteferon-gamma (IFN- $\gamma$ ) (18), that stimulates the resorptive activities of macrophages as its main function. These combined features may have resulted in a delay of the blood clot resorption (Figs. 1B, C, E, F, H and I). Macrophages are also able to produce several cytokines that affect the functions of different cells involved in the inflammatory and repair process (17). Once the viability of macrophages in the repair site is reduced, many of the cytokines stimulating fibroblasts tend to have lower levels. As several of these growth factors act on chemotaxis, proliferation, production and maturation of collagen, perhaps a deficiency in the formation of granulation tissue occurred, thus inhibiting the reparative functions of fibroblasts.

The histometric analysis demonstrated a significant decrease in the percentage of new synthesized bone in the animals that had coffee for a long period $(p \leq 0.01)$ compared 
to control, and the daily intraperitoneal administration of caffeine (CAF) produced the lowest amount of bone inside the dental socket, in relation to the control and coffee groups ( $p \leq 0.01$ ) (Fig. 2).

The action mechanisms of coffee/caffeine on bone remodeling are not entirely clear and can be direct and indirect. The indirect actions may occur secondarily to changes in mineral bone homeostasis (calcium and phosphorus), or through changes in hormones or absorption and excretion regulators of these minerals $(6,18)$. Evidence for direct actions of caffeine in the metabolism of bone cells was mainly obtained in studies of cell culture, showing changes in both osteoblasts and osteoclasts $(19,20)$.

The quality evaluation of bone repair process in the dental socket of animals treated with coffee or caffeine revealed that the newly formed bone trabeculae did not have suitable maturity even on $21^{\text {st }}$ and $42^{\text {nd }}$ days post extraction (Figs. 1B, C, E, F, H and I). Instead of a thick, well-formed and mature bone like in control (Figs. 1A, D and $\mathrm{G})$, much more connective tissue and blood clot still persisted in the bone defect.

Many studies have demonstrated that caffeine acts directly on osteoblasts and osteocytes disturbing the process of differentiation (20) multiplication (9), bone matrix production and mineralization (20), even leading to apoptosis of these cells (21). In osteoclasts, it is suggested that the presence of caffeine may increase the differentiation of these cells with the consequent decrease of bone mineral density (19).

Camargo et al. (22) reported that the average concentration of caffeine in boiled coffee is $0.67 \mathrm{mg} / \mathrm{mL}$. In the present study it was found that the average of coffee consumption by animals ( $\mathrm{CO}$ group) during the treatment period was $15 \mathrm{~mL} /$ day, therefore an average quantity/day of $10.5 \mathrm{mg}$ of caffeine was ingested by the animals. In the group treated with pure caffeine by intraperitoneal injections (CAF), the animals received an average dose of $15.6 \mathrm{mg} / \mathrm{animal} / \mathrm{day}$, what was calculated by the mean of every single dose received daily during the experimental period.

Regarding the mode of administration of caffeine, Wang and Lau (23) demonstrated that the pharmacokinetic and behavioral effects are similar with oral or intraperitoneal route of administration. Thus, the possible more aggressive deleterious effect of caffeine solution on the intraalveolar process of bone healing compared to the coffee intake possibly occurred by the difference in the final concentration of caffeine for both compared groups, since in $\mathrm{CO}$ group the average concentration during the study was $10.5 \mathrm{mg} /$ animal/day, for CAF group it was $15.6 \mathrm{mg} /$ animal/day. Besides the difference in the received dose for each group, the concentration of caffeine in relation to the vehicle was greater for animals receiving caffeine intraperitoneally, because for a concentration of $15.6 \mathrm{mg}$, $1.04 \mathrm{~mL}$ of $1.5 \%$ caffeine was required. In animals ingesting coffee, the concentration to obtain $10.5 \mathrm{mg}$ of caffeine was approximately $15 \mathrm{~mL}$ of boiled coffee, in other words, a larger amount of solvent, in this case water, was present. Therefore, possibly the presence of water decreased the concentration of caffeine in the body, facilitating the kidney clearance of the substance. In addition to caffeine, coffee has several other substances such as chlorogenic acid, niacin, and amino acids, substances beneficial to the organism in general (24), thus the synergism of these features may have slowed down the deleterious effects relative to pure caffeine.

High doses of caffeine have been reported as responsible for the decrease in cell viability of osteoblasts by stimulating intracellular oxidative processes (21). Possibly in CAF group there was greater plasma concentration of caffeine compared to the $\mathrm{CO}$ group, consequently higher bioavailability during the healing process after tooth extraction. This increased supply in the repair site possibly led to changes in intracellular mediators and thus to a lower viability and activity of osteoblasts to synthesize bone matrix, as evidenced in several studies $(8,20,21)$, and also higher osteoclastic activity (19), which may have provided low maturity of bone trabeculae with the use of pure caffeine (Figs. 1F, I). In combination with these direct actions, probably an increase of indirect actions by pure caffeine led to a greater loss of calcium in the urine (6), since it contained proportionally smaller amount of water than coffee, which may have hindered the mineralization process of the newly synthesized osteoid matrix.

The results of the present study confirm those of Lacerda et al. (6), who observed a lower percentage of alveolar bone after tooth extraction associated with daily ingestion of coffee, and Macedo et al. (9), who reported a delay in bone formation with the use of autogenous bone as graft material. It also corroborates the findings of another study (10) in which caffeine injected intraperitoneally was able to potentialize the disturbances of bone metabolism caused by induced osteoporosis in rats. On the other hand, $\mathrm{Ng}$ et al. (25) demonstrated clinically a protective effect of coffee consumption on periodontal bone loss. Maybe this feature was due to the presence of caffeine, which caused a reduction of mediator levels, leading to a consequent decrease in the inflammatory reaction and the pathway for bone resorption. This outcome should be analyzed carefully when compared to the present study, since the model of dental extraction that was used must have the inflammatory reaction to properly re-establish the alveolar bone architecture and the inflammatory reaction during periodontal disease, to a certain extent, acts as harmful 
factor to bone metabolism.

These results cannot fully explain the intrinsic mechanisms involved in the process of molecular action of coffee or caffeine on cells responsible for bone repair inside the dental socket. However, knowing the great number of procedures involving bone tissue which are performed daily around the world, and also that the caffeine contained in coffee or other supplements is widely consumed, this study may suggest the impact of this substance in the alveolar bone repair process.

It may be concluded that both the daily intake of boiled coffee since pregnancy and continuing to born animals until adult age as well as the intraperitoneal administration of caffeine for a determined period of time in rats caused damage to the alveolar bone tissue repair process after tooth extraction, with a significant delay in bone deposition. Changes in the reparative chronology were markedly more evident when pure caffeine solution was used.

\section{Resumo}

Estudos têm sugerido que a cafeína age sobre o osso promovendo um aumento da excreção de cálcio, inibição da proliferação dos osteoblastos e retardo no processo de reparação tecidual, aumentando o risco de fraturas, osteoporose, doença periodontal, bem como afetando o sucesso de ङ procedimentos de reconstrução óssea. 0 objetivo deste estudo foi analisar histomorfometricamente o processo de reparação óssea alveolar após extração dentária em ratos submetidos à ingestão diária de café fervido ou a administração intraperitoneal de cafeína. 45 ratos machos foram divididos de acordo com o tratamento, em controle (C); café (CO), tratados com café ¿ desde o nascimento; e cafeina (CAF), injeção intraperitoneal de solução aquosa de cafeina de 1,5\% $(0,2 \mathrm{~mL} / 100 \mathrm{~g}$ de peso corporal) durante 30 dias. Quando pesavam entre 250-300 g os animais foram anestesiados, submetidos à extração do incisivo superior direito, e sacrificados em 7, 21 e 42 dias após a cirurgia para análises histológicas quanto ao volume e à qualidade do osso formado no alvéolo dental. Os resultados qualitativos demonstraram grandes quantidades de coágulo sanguíneo e osso imaturo nos animais tratados com cafeína pura, em relação aos grupos café e controle. A avaliação histométrica mostrou que o tratamento com o café levou a uma queda na formação óssea de $40 \%$, e com a cafeína de $60 \%$ em comparação ao grupo controle (ANOVA $p \leq 0,01$ ). Concluiu-se que tanto a ingestão diária de café quanto a administração intraperitoneal de cafeina em ratos retardou o processo de reparação do osso alveolar após extração dentária, e este efeito é mais agressivo quando do uso da cafeina pura.

\section{Acknowledgements}

The authors thank. Adriana M. G. Silva, Edna A. S. Moraes, Gilberto André e Silva and Kleber A. Loureiro for technical assistance.

\section{References}

1. Johansen JR. Repair of the post-extraction alveolus in the Wistar rat: a histologic and autoradiographic study. Acta Odontol Scand 1970;28:441-461.

2. Devlin H, Sloan P. Early bone healing events in the human extraction sockets. Int J Oral Maxilofac Surg 2002;31:641-645.

3. Ahn JJ, Shin HI. Bone tissue formation in extraction sockets from sites with advanced periodontal disease: a histomorphometric study in humans. Int J Oral Maxillofac Implants. 2008;23:1133-1138.

4. Barone JJ, Grice HC. Seventh International Caffeine. Workshop. Food Chem Toxicol 1994:32:65-77.
5. Sugiyama $\mathrm{K}, \mathrm{He} \mathrm{P}$, Wada $\mathrm{S}$. Teas and other beverages suppress D-galactosamine-induced liver injury in rats. J Nutr 1999;129:13611367.

6. Lacerda SA, Matuoka RI, Macedo RM, Petenusci SO, Campos AA, Brentegani LG. Bone quality associated with daily intake of coffee: a biochemical, radiographic and histometric study. Braz Dent J 2010;21:199-204.

7. Bezerra JP, de Siqueira A, Pires AG, Marques MR, Duarte PM, Bastos MF. Effects of estrogen deficiency and/or caffeine intake on alveolar bone loss, density, and healing: a study in rats. J Periodontol 2013;84:839-849.

8. Kamagata-Kiyoura Y, Ohta M, Cheuk G, Yazdani M, Saltzman MJ, Nakamoto T. Combined effects of caffeine and prostaglandin E2 on the proliferation of osteoblast-like cells (UMR106-01). J Periodont 1999;70:283-288.

9. Macedo RM, Lacerda SA, Brentegani LG, Bombonato-Prado KF, Prata CA. Osseointegration of autogenous bone graft associated with osteoblastic cells under treatment with caffeine. Implant Dent 2011;20:369-373.

10. Macedo RM, Brentegani LG, Lacerda SA. Effects of caffeine on bones of osteoporotic rats. Journal of Caffeine Research 2012;2:140-145.

11. Hallström H, Byberg L, Glynn A, Lemming EW, Wolk A, Michaëlsson K. Long-term coffee consumption in relation to fracture risk and bone mineral density in women. Am J Epidemiol 2013;178:898-909.

12. Rapuri $P B$, Gallagher JC, Nawaz Z. Caffeine decreases vitamin D receptor protein expression and $1,25(\mathrm{OH})_{2} \mathrm{D}_{3}$ stimulated alkaline phosphatase activity in human osteoblast cells. J Steroid Biochem Mol Biol 2007;103:368-371.

13. Conlisk AJ, Galuska DA. Is caffeine associated with bone mineral density in young adult women? Prev Med 2000;31:562-568.

14. Horrigan LA, Kelly JP, Connor TJ. Immunomodulatory effects of caffeine: Friend or foe? Pharmacol Therap 2006;111:877-892.

15. Jafari $M$, Rabani $A$.Studies on the mechanism of caffeine action in alveolar macrophages: Caffeine elevates cyclic adenosine monophosphate level and prostaglandin synthesis. Metabolism 2004;53:687-692.

16. Jafari $M$, Rabani $A$. Dose and time dependent effects of caffeine on superoxide release, cell survival and DNA fragmentation of alveolar macrophages from rat lung. Toxicology 2000;149:101-108.

17. Kumar V, Abbas A, Fausto N. Tissue renewal and repair: regeneration, healing, and fibrosis.. In: Patology - Pathologic Basis of Disease. Kumar V, Abbas A, Fausto N (Eds). Rio de Janeiro, RJ: Elsevier; 2005; pp. 91-124.

18. Heaney RP. Effects of caffeine on bone and the calcium economy. Food Chem Toxicol 2002;40:1263-1270.

19. Liu SH, Chen C, Yang RS, Yen YP, Yang YT, Tsai C. Caffeine enhances osteoclast differentiation from bone marrow hematopoietic cells and reduces bone mineral density in growing rats. J Orthop Res. 2011;29:954960.

20. Su SJ, Chang KL, Su SH, Yeh YT, Shyu HW, Chen KM. Caffeine regulates osteogenic differentiation and mineralization of primary adiposederived stem cells and a bone marrow stromal cell line. Int J Food Sci Nutr 2013;64:429-436.

21. Lu PZ, Lai CY, Chan WH. Caffeine induces cell death via activation of apoptotic signal and inactivation of survival signal in human osteoblasts. Int J Mol Sci 2008:9:698-718.

22. Camargo MCR, Toledo MCF. Caffeine content in Brazilian coffees. Ciênc Tecnol Aliment 1998;18:421-424.

23. Wang Y, Lau CE. Caffeine has similar pharmacokinetics and behavioral effects via the i.p. and p.o. routes of administration. Pharmacol Biochem Behav 1998;60:271-278.

24. Trugo L. Coffee. In: Encyclopedia of Food Sciences and Nutrition (10 volumes). Caballero B, Trugo L, Finglas P. (Eds). England: Academic Press; 2003.

25. NG N, Kaye EK, Garcia RI. Coffee consumption and periodontal disease in males. J Periodontol 2014;85:1042-1049.

Received September 9, 2014 Accepted December 27, 2014 